\title{
Does Market Orientation Impact Customer Satisfaction? Evidence from the Banking Industry in Uganda
}

\author{
Kato M. I. Isaiah ${ }^{1} \&$ Peter K. Turyakira ${ }^{2}$ \\ ${ }^{1}$ College of Business and Management Sciences, Makerere University, Uganda \\ 2 Department of Marketing and Management, School of Business, College of Business and Management \\ Sciences (COBAMS), Makerere University, Uganda \\ Correspondent: Peter Turyakira, Department of Marketing and Management, Makerere University, PO Box 7062 \\ Kampala, Uganda. Email: pturyakira@gmail.com; pturyakira@bams.mak.ac.ug
}

Received: January 10, 2019

doi:10.5539/ijbm.v14n4p19

\begin{abstract}
Market orientation is considered a strategy designed to creating greater value for customers. This requires designing marketing strategies to better satisfy customers' needs. However, very few business organizations in Uganda have adopted market orientation, particularly the banking industry. Some commercial banks' customers continue to express their dissatisfaction over the quality of service delivered by some banks to meet their desires. Although scholars have developed interest in market orientation and customer satisfaction, academic and empirical studies particularly in Uganda are insufficient. This paper is intended to establish the correlation between market orientation and customer satisfaction in the banking industry. Data from 175 personal and corporate banking customers of Stanbic Bank Uganda Ltd was collected using a structured, self-administered questionnaire. The findings of this study reveal a substantial effect of market orientation on customer satisfaction.
\end{abstract}

Keywords: market orientation, superior value, customer satisfaction

\section{Introduction and Problem Statement}

Firms today are required to truly consider the needs of customers by offering quality products that meet or exceed their expectations (Egboro, 2015, p. 41). Business organizations should also continuously create and maintain superior value for their customers. Weinstein (2012) reveals that highly satisfied customers stay loyal, talk positively about the firm and its products. Organizations are expected to satisfy their current and potential customer needs by demonstrating commitment and being responsive to customer needs (Osuagwu \& Obaji, 2009, p. 69).

Maintaining superior customer value poses serious challenges to business firms today. One of the strategies to achieve this is to fully adopt a market orientation culture (Vutete \& Kuguyo, 2016, p. 92) has attracted academic and practitioner attentions for many. This requires conducting and executing research on various aspects of market orientation. Furthermore, market orientation is considered a strategy designed to creating greater value for customers; and market-orientated businesses are likely to understand their customers better and satisfy their needs accordingly (Gray \& Hooley, 2002, p. 982). This implies designing and implementing activities with the intention of satisfying customer requirements.

Most scholars and practitioners in marketing have dedicated their energies in the investigation of market orientation and its effects on organisational performance (Muumob, 2016, p. 1). Indeed, previous studies (Akomea \& Yeboah, 2011; Hinson \& Mahmoud, 2011) have indicated that market oriented organizations are likely to yield better results compared to less market oriented ones. However, some studies (Kirca, Jayachandran \& Bearden, 2005; Schalk, 2008) indicate that market orientation enhances customer satisfaction as well. According to Muumob (2016, p. 2), customer satisfaction is critical to meeting various needs of firms and society at large.

It should be noted that customers' needs are constantly changing, mainly in the service sector such as banks. Therefore, banks are required to continuously study their consumers to identify their needs and satisfy them accordingly (Muumob, 2016, p. 3). As such, the banking sector should focus on delivering superior quality service if they are to achieve high levels of customer satisfaction. To achieve this, banks in Uganda must fully 
understand what market orientation is and its linkage to customer satisfaction.

Regardless of its role in enhancing customer contentment, the adoption of market orientation strategy by businesses in Uganda has been undoubtedly low. As such, customer satisfaction has persistently been and continues to be a serious challenge to most business firms, especially the service sector. Some customers in commercial banks have and still continue to express their dissatisfaction with the service provision. Despite enormous efforts made by the commercial banks in Uganda to improve service delivery by adopting an electronic banking system, customers have continued to express their dissatisfaction over security and responsiveness of the electronic banking system (Matovu, Akisimire \& Mirembe, 2015). Furthermore, Burani, Arhur, Turyahebwa, Byamukama \& Sumil (2013) reveal that most commercial banks' customers in KampalaUganda raised their dissatisfaction over the unreliability of the service delivery offered by banks. In explication, Burani et al (2013) note that some bank personnel in Uganda were impolite towards customers. Such low customer satisfaction by the bank customers could be attributed to low adoption of market orientation strategies. Although scholars have developed interest in market orientation and customer satisfaction, academic and empirical studies particularly in Uganda are insufficient. Hence, this paper is intended to establish the impact that market orientation has customer satisfaction.

\section{Market Orientation and Customer Satisfaction}

Market orientation is a concept which emphasizes putting customers at the centre of a business's operations and delivering value to customers (Ozkaya, Droge, Hult, Calantone \& Ozkaya, 2015). According to Osuagwu \& Obaji, (2009, p. 68), a market oriented firm should do everything possible to satisfy its customers because of the impact that market orientation has on customer satisfaction. The ability of an organization to appreciate the current and future desires of its clients depends much on the firm's commitment to market orientation activities. As such, market oriented organizations are required to continuously understand the desires of their customers thereby modifying their offerings to satisfy those needs. This implies that highly market oriented firms are in a position to meet or exceed their customers' expectations effectively. Furthermore, market oriented organizations are likely to have great attention to offering superior services; which may in turn enhance satisfaction in (Webb et al., 2000).

Previous studies (Webb et al., 2000; Lings \& Greenley, 2009; O'Cass \& Ngo, 2011; Ashour, 2014; Yukse, 2010; Zebal \& Quazi, 2011) support the link between market orientation and customer satisfaction. Relatedly, Kirca et al.; (2005) reveal that market orientation enhances customer satisfaction which consequently is likely to improve overall performance. However, the study by Krepapa, Berthon, Webb \& Pitt (2000) is distinctive from other studies since it observes the relationship from the viewpoint of the market orientation perception. On the other hand, research by Krepapa et al (2000) reveals that the perceptual gap between organizations and their customers is inversely proportional to customer satisfaction. A number of studies (Schalk, 2008; Lings \& Greenley, 2009; O' Cass \& Ngo, 2011; Ashour, 2014; Zebal \& Quazi, 2011) have ignored the perceptions of customers altogether.

To conclude this review, perceptions of customers in this study have been ignored yet all activities executed by organizations should be focused on satisfying customers. Views of customers are pertinent as they enable organizations to adjust their marketing strategies in a way that will enable them to satisfy their customers better than the competitors.

\section{Methodology}

This section presents the research design and methodology that were used to address the objectives therein.

\subsection{Research Design}

This study was cross- sectional in nature and survey design in which quantitative data were collected. A quantitative research approach was utilised in this study because it allowed analysis of the relationships between the respective variables through appropriate statistical techniques.

From a study population of 323 personal and corporate banking customers of Stanbic Bank Uganda Ltd- Kasana Luwero branch, a sample size of 175 was determined through Krejcie and Morgan (1970) sample size selection table. Stratified random sampling was applied to this study because the study population was heterogeneous as it comprised personal and corporate banking clients. Thereafter, simple random sampling was used to get the respective sample elements from the categories of the population. Finally, purposive sampling was applied to identify those individuals who were judged knowledgeable to answer the survey questionnaires in a reliable manner. Data were obtained from respondents using self-administered questionnaires. The questionnaires, some of which were adopted while others derived from literature review had two sections. Section A required 
demographic information relating to respondents using a nominal scale. Section B of the questionnaire had statements on the study variables based on a 5-point Likert-type interval scale.

\subsection{Data Analysis}

The data obtained from the questionnaires were subjected to Statistical Package for Social Sciences (version 20) to check for errors, validation and cleansing. Thereafter, data were analysed to establish the correlation between the respective variables; particularly the effect of market orientation on customer satisfaction in the banking industry. The mean, standard deviations and regression were also obtained.

\section{Presentation and Analysis of Results}

\subsection{Demographic Profile of Respondents}

The study explored various demographic profiles of customers that included age, sex, education attained and years worked in the current role. The vast majority of respondents was females $(51.2 \%)$ aged 26-35 years (32.9\%). Most of the respondents (39.0\%) had attained a Diploma and had been operating between one and five years $(41.5 \%)$.

\subsection{Market Orientation and Customer Satisfaction}

The findings about the impact of market orientation on customer satisfaction are summarized in Table 1 below.

Table 1. Correlation analysis

\begin{tabular}{llcc}
\hline & \multicolumn{2}{c}{ market orientationcustomer satisfaction } \\
\hline \multirow{5}{*}{ market orientation } & Pearson Correlation1 & $.937^{* *}$ \\
& Sig. (2-tailed) & .000 \\
& $\mathrm{~N}$ & 164 & 164 \\
& Pearson Correlation. $937^{* *}$ & 1 \\
\multicolumn{1}{l}{ customer satisfactionSig. (2-tailed) } & .000 & \\
& $\mathrm{~N}$ & 164 & 164 \\
\hline
\end{tabular}

**. Correlation is significant at the 0.01 level (2-tailed).

As indicated in Table 1 above, the effect of market orientation on customer satisfaction was explored through Pearson's correlation coefficient. The value of Pearson's $r$ was 0.937 (93.7\%) at $99 \%$ confidence level. This implies that the higher the adoption of market orientation strategies by business organizations, the more customers will be satisfied with their services. Hence, as values of market orientation rise, the values of customer satisfaction are likely to consequently correspond.

\subsection{Regression Analysis}

Table 2. Regression analysis

$\begin{aligned} & \text { Model Summary } \\
& \text { ModelR }\end{aligned}$ R SquareAdjusted R SquareStd. Error of the Estimate
\begin{tabular}{llll}
\hline 1 & $.937^{\mathrm{a}} .878$ & .877 & 1.33032 \\
\hline
\end{tabular}

a. Predictors: (Constant), market orientation.

b. Dependent Variable: customer satisfaction.

Table 2 above indicates that market orientation is considered one of the predictors of customer satisfaction which is a dependent variable. It shows that the regression coefficient (R Square) is 0.878 implying that $87.8 \%$ of the variation in customer satisfaction may be explained by market orientation while the remaining $12.2 \%$ can be elucidated by other factors. 
Table 3. Regression variance analysis

\begin{tabular}{lllll}
\hline $\begin{array}{l}\text { ANOVA }^{\mathrm{a}} \\
\text { Model }\end{array}$ & Sum of Squares & df & Mean Square & F \\
\hline \multicolumn{1}{c}{ Regression } & 2058.083 & 1 & 2058.083 & 1162.929 \\
1 Residual & 286.698 & 162 & 1.770 & $.000^{\text {b }}$ \\
Total & 2344.780 & 163 & & \\
\hline
\end{tabular}

a. Dependent Variable: customer satisfaction.

b. Predictors: (Constant), market orientation.

Table 3 above reveals that the test of impact for the F-statistic (1162.929) is less than 0.05 which implies that market orientation can considerably predict customer satisfaction.

Table 4. Coefficients

\begin{tabular}{|c|c|c|c|c|c|}
\hline \multicolumn{6}{|l|}{ Coefficients $^{\mathrm{a}}$} \\
\hline \multirow[t]{2}{*}{ Model } & \multicolumn{3}{|c|}{ Unstandardized CoefficientsStandardized Coefficientst } & \multicolumn{2}{|c|}{ Sig. $95.0 \%$ Confidence Interval for $\mathrm{E}$} \\
\hline & $\mathrm{B}$ & Std. Error & Beta & Lower Bound & Upper Bound \\
\hline (Constant) & -2.238 & .531 & & $-4.210 .000-3.287$ & -1.188 \\
\hline market orie & n.366 & .011 & .937 & 34.102 .000 .345 & .387 \\
\hline
\end{tabular}

a. Dependent Variable: customer satisfaction.

Table 4 above reveals that the constant value is -2.238 , the unstandardized coefficient for the independent variable (market orientation) is 0.366 and the p-value associated with this coefficient is less than 0.05 . Hence, customer satisfaction can be predicted significantly using the values for market orientation, with every unit increase in market orientation resulting into an increase in customer satisfaction by 0.366 units.

\section{Discussion of Results, Conclusions and Recommendations}

The study findings have shown a strong impact of market orientation on customer satisfaction. This finding is in agreement with the previous studies by Webb et al., (2000); Kirca et al., (2005); Schalk, (2008); Lings \& Greenley (2009); O' Cass \& Ngo (2011); Ashour (2014); and Zebal \& Quazi (2011) whose findings reveal a strong impact of market orientation on customer satisfaction; though they used different techniques to achieve the same result. Hence, the more an organization conducts market orientation activities, the higher chances of satisfying its customers.

Furthermore, the findings of regression analysis reveal that market orientation has a strong positive impact on customer satisfaction. This suggests that market orientation significantly contributes to variations in customer satisfaction with $87.8 \%$ of the variance in customer satisfaction being attributed to market orientation. Relatedly, market orientation can considerably improve customer satisfaction with a unit increase in market orientation resulting into an increase in customer satisfaction by 0.366 units. This finding is also in support of the previous studies by Kirca et al (2005); Schalk (2008); and Zebal \& Quazi (2011).

It should also be appreciated that findings of this study have disclosed a strong influence of market orientation on customer satisfaction in the banking industry in Uganda. For the commercial banks to achieve high customer satisfaction in Uganda, they need to revise their policies and incorporate market orientation activities in their strategic plans. Hence there is need for commercial banks to heavily invest in market orientation if they are to attract and retain satisfied customers. Commercial banks in Uganda should also go back to the grass roots if they are to appreciate the desires of their current and potential customers by executing market research on customer orientation. This will enable banks' management to realign its marketing strategies to the effective satisfaction of their customers' needs.

\section{Limitations and Future Research}

It should be noted that results of study cannot be generalized since the research data is restricted to the banking sector only. Therefore, further research should be conducted not only in the service (banking) sector but also in the manufacturing industry in Uganda in order to provide more insights about market orientation and customer satisfaction. It should also be noted that bank employees were not considered as part of the study population yet their views could be fundamental in this endeavour. Otherwise, customers' clearly comprehend the concept of market orientation and its dimensions might be limited. Methodologically, the study relied on quantitative 
approach. In future, a triangulation should be utilised to get a deeper understanding of the research phenomenon.

\section{References}

Akomea, S. Y., \& Yeboah, J. K. G. (2011). Market Orientation and Firm Performance in Ghana's Pharmaceutical Industry. Journal of Science and Technology, 3(12), 109-119.

Ashour, M. L. M. (2014). Marketing orientation, customer satisfaction and retention. The case of telecommunications services market in Jordan. Doctoral thesis, University of Hertfordshire, Jordan.

Burani, A., Arhur, S., Turyahebwa, A., Byamukama, E., \& Sumil, M. (2013). An assessment of degree of service quality of some selected commercial banks in central Uganda. Perception of Bank Customers. International Journal of Engineering Research and Technology, 2(2), 1-17.

Egboro, F. (2015). Marketing challenges of satisfying consumers changing Expectations and preferences in a competitive market. International Journal of Marketing Studies, 7(5), 41-52.

Gray, B. J., \& Hooley, G. J. (2002). Market orientation and service firm performance - a research agenda. European Journal of Marketing, 36(9/10), 980-988. https://doi.org/10.1108/03090560210437280

Kirca, A. H., Jayachandran, S., \& Bearden, W. O. (2005). Market orientation: A Meta analytic review and assessment of its antecedents and impact on performance. Journal of Marketing, 69(2), 24-41. https://doi.org/10.1509/jmkg.69.2.24.60761

Krepapa, A., Berthon, P., Webb, D., \& Pitt, L. (2000). Market orientation and customer satisfaction in the service dyad (No.6). University of Bath, School of Management, Working paper.

Lings, I., \& Greenley, G. (2009). The impact of internal and external market orientations on firm performance. Journal of Strategic Marketing, 17(1), 41-53. https://doi.org/10.1080/09652540802619251

Matovu, A., Akisimire, R., \& Mirembe,R (2015). Customer satisfaction in retail banks: does service quality and electronic banking adoption matter? Evidence from a Developing Country. African Business and Management Research Journal, 1(1), 25-44.

Muumob, D. D. (2016). Market orientation practices and customer satisfaction in the Ghananian Banking sector. Unpublished MPhil thesis, University of Ghana.

O'Cass, A., \& Ngo, L.V. (2011). Achieving customer satisfaction via market orientation, brand orientation and customer empowerment: Evidence from Australia. Journal of Services Marketing, 25(7), 489-496. https://doi.org/10.1108/08876041111173615

Osuagwu, L., \& Obaji, R. (2009). Market orientation in Nigerian Manufacturing Companies. International Business \& Economics Research Journal, 8(9), 67-72.

Ozkaya, H. E., Droge, C., Hult, G. T. M., Calantone, R., \& Ozkaya, E. (2015). Market orientation, knowledge competence and innovation. International Journal of Research in Marketing, 32(3), 309-318. https://doi.org/10.1016/j.ijresmar.2014.10.004

Valter, A.V. (2010). Antecedents and consequences of market orientation: A Brazilian meta-analysis and an international mega-analysis. Brazillian Administration Review, Curitiba, 7(1), 40-58. https://doi.org/10.1590/S1807-76922010000100004

Webb, D., Webster, C., \& Krepapa, A. (2000). An exploration of the meaning and outcomes of a customer-defined market orientation. Journal of Business Research, 48(2), 101-112. https://doi.org/10.1016/S0148-2963(98)00114-3

Weinstein, A. (2012). Superior customer value: Strategies for winning and retaining customers (3rd ed.). Boca Raton, Florida: CRC Press-Taylor \& Francis Group.

Yukse, A. (2010). Effects of customer satisfaction on customer loyalty. Journal of Marketing Management, 2(1), 274-284.

Zebal, M. A., \& Quazi, A. (2011). Investigating the determinants and outcomes of market orientation: Evidence from Bangladesh banks. International Journal of Management and Marketing Research, 4(2), 35-47.

\section{Copyrights}

Copyright for this article is retained by the author(s), with first publication rights granted to the journal.

This is an open-access article distributed under the terms and conditions of the Creative Commons Attribution license (http://creativecommons.org/licenses/by/4.0/). 